Article

\title{
Impact of Climate Change on Wine Tourism: An Approach through Social Media Data
}

\author{
Veronica Alampi Sottini, Elena Barbierato $\mathbb{D}$, Iacopo Bernetti * ${ }^{\mathbb{B}}$ and Irene Capecchi \\ DAGRI, Department of Agricultural, Food, Environmental and Forestry, University of Florence, \\ Piazzale delle Cascine, 18-50144 Firenze, FI, Italy; veronica.alampi@unifi.it (V.A.S.); \\ elena.barbierato@unifi.it (E.B.); irene.capecchi@unifi.it (I.C.) \\ * Correspondence: iacopo.bernetti@unifi.it
}

Citation: Sottini, V.A.; Barbierato, E.; Bernetti, I.; Capecchi, I. Impact of Climate Change on Wine Tourism: An Approach through Social Media Data. Sustainability 2021, 13, 7489. https://doi.org/10.3390/su13137489

Academic Editor: Colin Michael Hall

Received: 14 June 2021

Accepted: 29 June 2021

Published: 5 July 2021

Publisher's Note: MDPI stays neutral with regard to jurisdictional claims in published maps and institutional affiliations.

Copyright: (c) 2021 by the authors. Licensee MDPI, Basel, Switzerland. This article is an open access article distributed under the terms and conditions of the Creative Commons Attribution (CC BY) license (https:// creativecommons.org/licenses/by/ $4.0 /)$.

\begin{abstract}
Wine tourism is one of the best opportunities for rural development, but because it is partially exposed to climatic conditions, it is a climate-vulnerable tourism activity. However, an understanding of the potential impacts of global climate change on this popular activity remains limited. This study proposes a new methodology that combines current daily gridded climate data from the E-OBS project with big spatiotemporal data from the Flickr photo-sharing platform through a generalized additive model This methodology was implemented to study the potential impacts on tourism flows due to climate change and to make predictions about the future using data from the CMIP5 project. We applied the methodology to 5 European wine tourism regions: Alsace (FR), Chianti (IT), La Rioja (SP), Langhe-Monferrato (IT), and Moselle (DE). Results show an increased probability of presence and increased deseasonalization of tourism in all study areas and an anticipation of peak presence from summer to spring in three of the five regions. We believe that these results can be useful for public and private stakeholders to adapt the offer of wine tourism services to changes in demand and to direct the organization of events such as festivals and thematic tours.
\end{abstract}

Keywords: wine tourism; climate change; Copernicus Climate Change Service; Flickr; generalized addictive model

\section{Introduction}

\subsection{General Problem}

Wine tourism is a journey aimed at discovering the wine offer of a territory and through which tourists can experience the local culture and acquire a sense of the place. Hall [1] (p. 50) defined it as the "visitation to vineyards, wineries, wine festivals and wine shows for which grape wine tasting and/or experiencing the attributes of a grape wine region are the prime motivating factors for visitors".

Wine tourism is one of the best opportunities for sustainable rural development in many regions around the world. Direct sales in the cellar allows for greater employment and is therefore an important factor for economic development, preventing the abandonment of the countryside. Thanks to wine tourism, cultural ecosystem services are also achieved through the relationship between consumer, wine producer, and landscape [2,3].

However, wine tourism does not only include visits to cellars, parties, and the purchase of wine; the climate of the wine region is an integral part of the wine tourism experience. Many authors highlighted that the pleasantness of the climate is an important factor for tourist satisfaction. Through a sample of 161 wine consumers in Calgary (Canada), Getz and Brown [4] found that a pleasant climate all year round is one of the factors included in the "core destination appeal". Through a principal component analysis, Galloway et al. [5] confirmed that a good climate is one of the most important dimensions of the "aesthetic characteristic" of a wine region. Applying a non-probabilistic procedure through unstructured questionnaires to potential wine tourists in Aragona, March-Navarro, and Pedraja-Iglesias [6] found that the climate of the area is one of the aspects to which the 
interviewees attributed the highest average values of importance among the various items concerning the intention to participate in wine tourism.

Wine tourism takes place partly outdoors (visiting the vineyard) and partly indoors (visiting the winery and wine tasting); therefore, being partially exposed to climatic conditions, wine tourism is vulnerable to climate. However, an understanding of the potential impacts of global climate change on this popular activity remains limited. The overall purpose of this work is to identify the climatic comfort of the wine tourist through a human ecology approach and examine how this comfort might vary due to climate change.

\subsection{Literature Review}

Climate change will have a direct impact on the tourism sector in Europe. Temperature increases and changes in rainfall patterns will alter the length and quality of tourism seasons in the region, affecting both the temporal and spatial distribution of flows to different destinations. The latest assessment report of the Intergovernmental Panel on Climate Change (IPCC) concluded that, "after 2050, tourism activity is expected to decrease in southern Europe (low confidence) and increase in northern and continental Europe (medium confidence)."

From a theoretical perspective, the study of the relationship between climate change and tourism can be referred to using the vulnerability-adaptation-mitigation-response framework. The difference between climate change mitigation and climate change adaptation strategies is that mitigation aims to address the causes and minimize the possible impacts of climate change, while adaptation looks at how to reduce the negative effects. Finally, response focuses on defining how society governs the impacts of climate change through specific policies. The present research is connected to the dimensions of impact and adaptation, and the literature review is oriented in this direction.

The study of the impact of climate change on tourism activities has been addressed by adopting many approaches. In this review, after screening the sparse existing literature on the specific topic of wine tourism, we attempted to categorize the extensive literature related to the impact of climate and climate change on other tourism activities. Finally, we reviewed the existing literature on modeling human ecology in relation to landscape characteristics.

Although numerous studies on the impact of climate change on tourism have been carried out since $1960[7,8]$, the only specific study on the impacts of climate change on wine tourism is the Sustainable Tourism Cooperative Research Centre's (STCRC) report "The Impacts of Climate Change on Australian Tourism Destinations: developing adaptation and response strategies-a scoping study" $[9,10]$. This study assessed the impacts and adaptation strategies for 2020, 2050, and 2070 through stakeholder interviews and social learning workshops. The results were contradictory. Tourists were asked the question: "What do you think will happen to tourism in the Margaret River region if the climate changes?" and most of the respondents answered that there would be "less tourism". A small percentage of the respondents indicated that they believed there would be "no change" for tourism in the Margaret River region. Other respondents who answered "more tourism" stated that changes in weather patterns would attract more visitors to Margaret River as other tourist destinations would become less hospitable. In contrast to tourists, local stakeholders mainly predicted a change in consumer behavior and a transition from beach tourism to wine tourism with consequently more visitors in the wine regions due to climatic change.

Only slightly more extensive is the literature on the impacts of climate change on rural tourism. Gomez-Martin et al. [11] carried out research on climate change adaptation strategies in the tourism sector in the Costa Brava (Spain). Through a methodology based on stakeholder questionnaires, the authors found out that most of the interviewees believed that rural tourism is a national adaptation strategy for the tourism sector as it is complementary to seaside tourism in the event of climate change. In an analysis relating to rural tourism in Hungary, Zsarnoczky [12] states that "climate change are 
expected to significantly reduce the resilience of rural tourism regions and their capability to successfully respond to other possible critical events".

From the review of the existing literature, it is evident that there is a lack of empirical quantitative studies on the risk of changing tourism flows in wine regions due to climate change.

Data collection remains one of the biggest challenge researchers face in measuring the impact of climate change on specific types of tourism activities. The methodologies for assessing the vulnerability of tourism to climate change differ in the collection of data for tourism presence and climate variables. The studies differ both in the origins of the data used to detect the behavior of the tourist and in the format of the climatic data adopted.

Some studies $[13,14]$ showed the possibility of using data from national statistics to examine the relationship between tourism and climate change. Despite these successful examples, these statistics are not sufficiently detailed. Most of the statistical data uses relatively coarse classifications (beach tourism, ski tourism, art tourism, and other tourist activities); for example, in Tuscany it is impossible to disaggregate wine tourism from tourism in cities of art; in European and Alpine areas it is not possible to distinguish wine tourism from nature tourism presences. Questionnaire surveys are aimed at detecting the ideal climatic conditions of the tourist $[15,16]$. The main drawback of this approach are the reliability of respondents' statements, who are generally not experts in biometeorology [17]; furthermore, these data are generally derived from small samples within short time intervals and refer to single locations. Techniques based on the so-called big data from social media platforms provide a new approach that can be usefully applied. Although these data have been used extensively in the last decade to study tourist behavior (see [18] for a review), there are few studies (mostly written in Chinese) aimed at climate comfort [19-22]. Ground-based weather station observations are the most widely used method for studying the climatic comfort of tourists, both through monthly average data [23] and daily data [24] However, these data have a limited spatial extent. Recently, with the increased availability of gridded spatial data, there has been an increase in the number of studies implementing them. Monthly gridded data have been applied to the analysis of the effect of temperature on visitors to National Parks. Fisichelli et al. [25] and Coldrey and Turpie [26] employed Climatic Research Unit (CRU) data available globally to 0.5 decimal degrees (approximately $3000 \mathrm{~km}^{2}$ at the Equator and $2000 \mathrm{~km}^{2}$ at $70^{\circ}$ latitude) in a regression analysis with the number of visitors surveyed monthly. Although this dataset is spatially coarse, it can be considered adequate at the scale of national parks. Thematic gridded data were employed by Scott et al. [27] to formulate the Holiday Climate Index (HCI). The authors employed the dataset for current climate (1961-1990) and future climate change scenarios from the EU-funded ENSEMBLES project [28] at $25 \mathrm{~km}$ resolution. Köber [29] used E-OBS gridded dataset version 5.0 on a $0.22^{\circ}$ rotated pole grid in order to construct the weather and climate indices used to calibrate tourism demand models in two regions in Italy and Tunisia. Finally, Perch-Nielsen [30] calculated the Touristic Climate Index (TCI) for tourism in Europe and projected changes under future climate change using daily data from five regional climate models and comparing the 1961-1990 baseline period with the A2 scenario in 2071-2100.

In ecology, the behavior of wild populations in relation to climate and climate change is studied by means of niche models or envelope models [31,32]. Niche models relate to the geographical points where an animal of a given species has been sighted to the climatic characteristics of that point. The model allows us to estimate the probability that a spatial location is the ecological niche of the studied species. The aim of our work is to apply this methodology to the wine tourist using as sighting points the coordinates of the shooting points downloaded from the social photographic platform Flickr. Flickr has recently been used by many authors to study the behavior of different types of tourists in relation to landscape variables using Niche Models.

Levin et al. [33] (p.122) have "found strong and significant correlations between all crowdsourced data and visitation statistics, demonstrating the potential to use crowd- 
sourced data to characterize the social and perceived importance of protected areas and as a proxy for visitation statistics". The authors demonstrated the advantages of combining remote sensing data and geotagged photos on Flickr to identify tourist frequency and monitor the impact of overload. Yoshimura and Hiura [34] and Walden-Schreiner et al. [35] analyzed the relationships between shooting locations of geo-referenced photos on Flickr with the environmental characteristics of the territory and the presence of infrastructure to provide management strategies for the conservation of natural resources, while providing opportunities for tourism and recreation. Urban green spaces have also been investigated with an ensemble of human niche models [36]. Recently, Alampi Sottini et al. [3,37] and Barbierato et al. [38] applied Flickr data to the landscape preferences of wine tourists in Tuscany (Italy).

\subsection{Purpose of the Research}

Our research aims to apply human niche models by correlating Flickr platform data with current and future climate variables. One of the main advantages of Flickr is that data are available worldwide, thus allowing us to implement the methodology in five European wine tourism regions: Alsace (FR), Chianti (IT), La Rioja (SP), Langhe-Monferrato (IT), and Moselle (DE).

Our study aims to contribute to the current literature in two ways. The first research question (RQ1) concerns the possibility of combining Flickr platform data with climate data to identify the probability of tourist presence with a specific focus on wine tourism, thus filling the gap of research on this sector. The second research question (RQ2) aims to quantitatively test the opinion expressed by wine tourists and farmers on the fact that wine tourism may represent an opportunity for the tourism sector to adapt to climate change [9].

\section{Materials and Methods}

\subsection{Study Areas}

We have chosen five wine regions in Europe based on two criteria: the development of wine tourism [39] and the diversification of climatic characteristics (Figure 1).

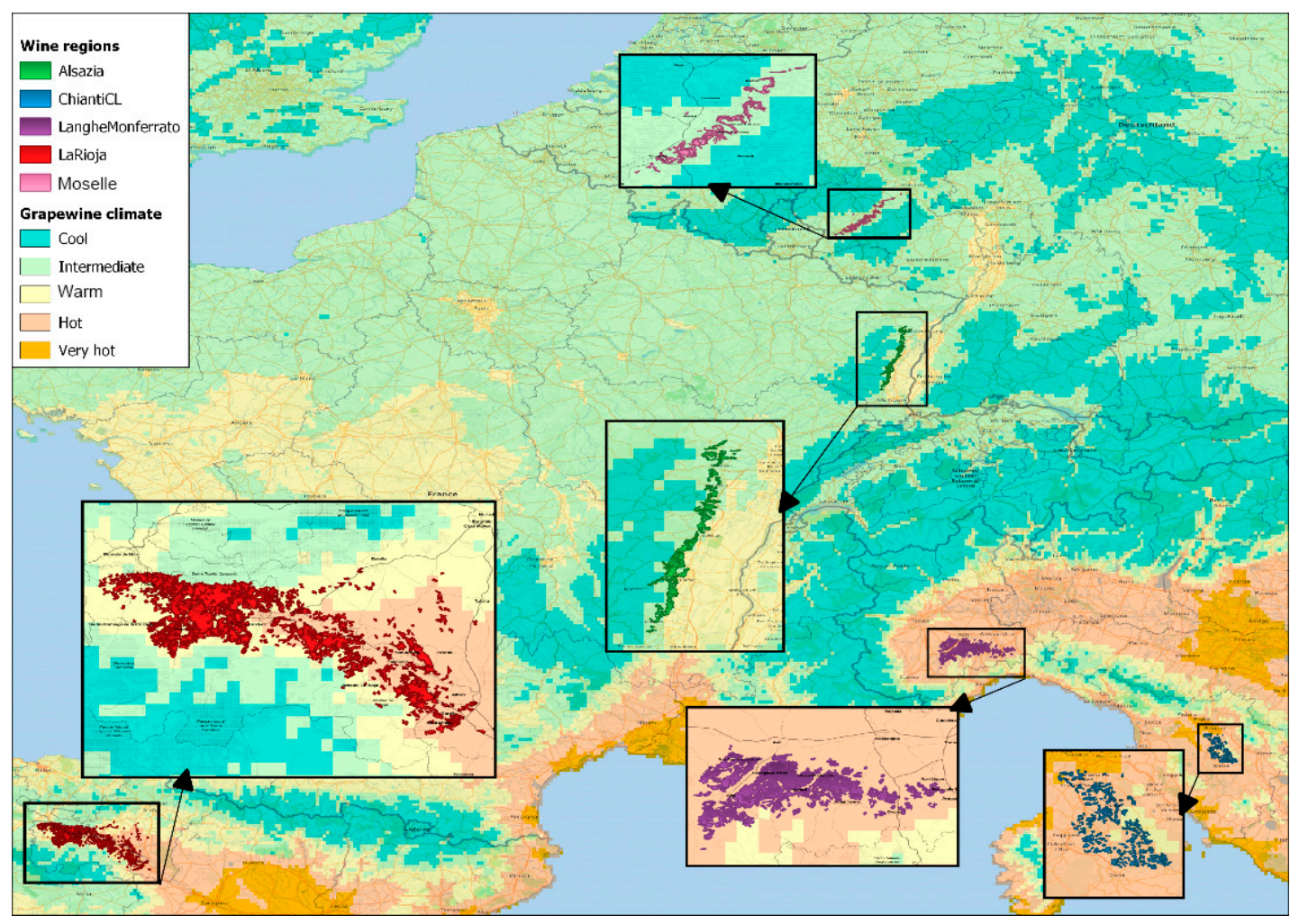

Figure 1. Study areas. 


\subsubsection{Alsace}

Alsace is a distinctly different French wine region, lying on the west bank of the river Rhine. It is protected by the Vosges Mountains and thus it benefits from a unique continental climate, characterized by little precipitation. Although located in the north-east of the country, Alsace is the driest and one of the sunniest regions of France with an annual average temperature around $1.5{ }^{\circ} \mathrm{C}$ higher than would be expected at its latitude. The climate is the ideal one for the full maturation of the different grape varieties cultivated here, favoring the full developing of their aroma and character. Moreover, the region is rich in history, picturesque architecture, and stunning landscape, which makes it a popular tourist destination all year round. As a matter of fact, the Alsace Wine Route is one of the oldest in France. It stretches $170 \mathrm{~km}$ across medieval villages, and is characterized by half-timbered houses decorated with flowers, castles, and Roman and Gothic churches [40].

\subsubsection{Chianti}

The Chianti region lays in the heart of Tuscany, delimited by the cities of Florence, Siena, and Pisa. Generally, the climate is continental, with cold winters and hot summers. However, most vineyards are located at the foot of the Apennine Mountains, which lower the heat of the summer. In addition, some areas are warmed by air currents funneled from coastal areas, making the winters less harsh than elsewhere.

Chianti stretches for $160 \mathrm{~km}$ from north to south, and it is thus characterized by different soils, temperatures, and altitudes. Thus, it is difficult to pinpoint common characteristics for the entire area. However, the region is mainly characterized by a rolling hilly landscape in which grapes and olive trees are cultivated extensively. The landscape is also dotted with farmhouses, castles, and ancient roads lined by cypress trees. The region is a tourist destination known worldwide for its rich history, cultural heritage, landscape, and refined gastronomy [41].

\subsubsection{La Rioja}

La Rioja is a province of Spain located in the north of the Iberian Peninsula. The well-known wine region also offers a great amount of religious and cultural variety. La Rioja is linked to the famous pilgrimage route of Saint James and boasts the San Millan Yuso and Suso monasteries, which are designated UNESCO World Heritage sites. Moreover, La Rioja offers a beautiful hilly landscape, dotted with fortresses from medieval times. Culture, natural attractions, and wine make this region a very popular tourist destination. In addition, the presence of the Cantabrian Mountains, which flank La Rioja to the north and west, protect the region from the cold and the wet influences of the Atlantic Ocean. This is a significant factor in the local climate, which is warmer and drier than that typical of northern climates [39].

\subsubsection{Langhe-Monferrato}

Monferrato and Langhe occupy an area of Piedmont that lies south of the river Po. Piedmont is located in the northwest corner of Italy, and this area between the foothills of the Alps and the Apennines is undoubtedly one of the most important winegrowing regions not only in Italy but also in the world. The name of the region, Piedmont, has medieval Latin origins: "ad pedem montium", which means "at the foot of the mountains".

The Monferrato, and Langhe to the south of it, occupy foothills branching off the Ligurian Appennines across the Casale area to the Po valley in a variety of geographical contours and landscapes. The area is surrounded by gently rolling hills, tiny hilltop villages, and broad landscapes of vineyards and fruit orchards. A network of mostly small roads connects these old villages and towns with each other, and many tourists visit this region throughout the year. The climate is continental with a strong Mediterranean influence, due to the Ligurian Riviera only $50 \mathrm{~km}$ away. The winters are short, and night temperatures in January and February only occasionally fall below zero. Spring and autumn are long and 
warm. The summers are hot and dry, although the hilltops are ventilated by a pleasant sea breeze [42].

\subsubsection{Moselle}

The Moselle wine region has a northerly continental climate characterized by cool temperatures. The region takes its name from the Moselle River, where we can find the best vineyard sites as the heat of the sun can be maximized by the reflection on the water flowing in the river. Together with the two small tributaries of the Moselle, the Saar and the Ruwer, Moselle is considered the oldest wine growing region in Germany. The soil of the area is dominated by porous slate which allows for ideal drainage and good heat retaining properties. During summer, the weather is warm but rarely hot with average temperatures around $18{ }^{\circ} \mathrm{C}$. Most of the vineyards are grown on steep and terraced sites with a slope of over 30 degrees, some planted at an astounding 70-degree gradient. The region is a highly attractive travel destination not only for its stunning outlooks into the valley, but also for the spectacular beauty of the hilly vineyards, which gives the region its quite unique character [43].

\subsection{Data}

\subsubsection{Flickr Social Media and Wine Tourist Data}

The voluntary sharing of personal information and content uploaded to various online social networks has created several opportunities for the analysis of tourist behavior. For the present research, several sources of information were initially considered: Twitter, Instagram, Facebook, Twitter, Panoramio, and Flickr. We decided to choose Flickr because it is widely used as a data source in the literature for the analysis of tourist behavior and destination choice [28]. Sessions et al. [44] recently reported positive results in predicting monthly visitor patterns in U.S. national parks using Flickr data. Similar results were obtained by Levin et al. [33]. Cox [45], in a questionnaire-based study, states that Flickr is the social platform for serious amateur photography enthusiasts on vacation. Liu et al. [46] showed that Flickr is the preferred social platform for sharing food and wine photos and that users search for food photos on Flickr to choose new destinations. A key feature for our research is that the data downloaded from Flickr allows us to know the exact date and time of the tourist's presence at the location through the EXIF photo metadata associated with the photo [47]. It also makes available an accessible and flexible application programming interface (API). Using the boundaries of each wine region, through an algorithm based on Flickr's application programming interface, shooting point data from photos shared from 1 January 2010 to 12 December 2019 were downloaded. For each shooting point, the following data were downloaded: longitude, latitude, date of photo shooting, owner, title, and description tags. The photo-points containing "wine", "vineyard", and related words in English, Italian, Spanish, French, and German in the title, tag, or description were filtered. Then, specific filters were applied to avoid distortions due to observations repeated several times on the same date by a single photographer.

\subsubsection{Climate Data}

To evaluate spatial and temporal variations, we used daily gridded climate data from the European Union's Copernicus Climate Change Service project (https:/ /cds.climate. copernicus.eu/, (accessed on 1 July 2021)). For the current climate we used the E-OBS version 18 gridded dataset [48] with a Regular latitude-longitude grid with $0.25^{\circ} \times 0.25^{\circ}$ resolution and daily data for the period from 1 January 2010 to 31 December 2019. For future climate we used data from the Coupled Model Intercomparison Project, CMIP5, [49] with a Regular latitude-longitude grid with $0.125^{\circ} \times 0.125^{\circ}$ resolution, related to RCP6.0 and the HadGEM2-ES model (UK Met Office, UK). In the case of total cloud cover, the Coordinated Regional Climate Downscaling Experiment (CORDEX) was model was used. The time periods considered were the following: 1 January 2010-31 December 2019 for the current climate, 1 January 2030-31 December 2039 and 1 January 2050-31 December 2059 
for the future climate. The choice of the RCP6.0 scenario is due to the fact that it represents a prudential assumption compared to the optimistic RCP2.5 and RCP4.5 scenarios, but not as overly pessimistic as the RCP8.5 scenario. The HadGEM2-ES model is part of a new generation of an earth system including models designed to analyze the potential impacts of climate change [50]. Finally, we chose recent time periods to model the probability of wine tourism presence and fairly close periods to assess future changes in order to provide useful information to stakeholders. The choice of meteorological variables was made on the basis of the existing literature [24,51-54]. In the model, we considered maximum, minimum, and average daily temperature, daily total runoff, wind speed, relative humidity, and total cloud cover.

\subsubsection{Joining Climate and Wine Tourist Data in a Single Dataset}

The next step was joining the gridded climatic data to the points of tourist presence through a geographic overlay operation on the grid, corresponding to the date the photo was taken. Our study aims to estimate the probability of a visitor's presence in one of the five wine regions at a given location, time, and with the resulting weather conditions. Therefore, all probabilistic algorithms require some form of absence observation that they use as a contrast to observations of tourist presence. When absence data are not available, pseudo-absence data must be generated. In spatial suitability models, we usually generate random coordinate pairs within the boundary of the study area. However, in our study it was also necessary to generate time pseudo-absence observations. Therefore, for each wine region we first generated a number of coordinate pairs equal to the number of points downloaded from Flickr. Each pseudo-absence coordinate was randomly assigned a date on which there were no photographs. The pseudo-absence points were also associated with the gridded climate data through a geographic overlay operation.

\subsection{Statistical Processing}

Recently, some studies have shown that the complexity of the relationship between people's behavior and climate factors are difficult to model through a linear function. As a result, non-parametric estimation approaches, such as the Generalized Additive Model (GAM), have been applied to model complex relationships [18,55]. We statistically estimated the relationship between climatic factors and the presence of wine tourists (measured with a binary variable of presence/pseudo-absence) using the GAM. The GAM is a flexible extension of the generalized linear model (GLM) in which the linear predictor of the GLM is replaced by a nonlinear additive predictor defined by a spline. The logistic GAM we used had the following structure:

$$
\operatorname{Pr}(Y=1 \mid X)=\log \left(\frac{p(X)}{1-p(X)}\right)=\beta_{0}+f_{1}\left(X_{1}\right)+f_{1}\left(X_{2}\right)+\cdots+f_{1 p}\left(X_{1 p}\right)
$$

where $f_{1}-f_{\mathrm{p}}$ are spline functions of the explanatory variables, $X_{i}$.

We used spline functions with four degrees of freedom and thus three nodes. The use of spline functions is used by some authors [56,57] to study the effect of climate change on tourism-related variables and allows an easier identification of discontinuity points and an easier comparison of results with those obtained from different studies. For the choice of the model with the best classification performance, we calculated the model with $85 \%$ of the observations and used the method of the area under the ROC curve (AUC) to estimate the remaining $15 \%$ of observations. The AUC is one of the most used methods to measure the efficiency of a binary classifier: AUC values of $0.6-0.7$ suggest a fairly accurate model, $0.7-0.8$ an accurate model, and greater than 0.8 a very accurate model [58]. The model that gave the best AUC performance and parameter significance was the following:

$$
\operatorname{Pr}(\text { Flickr }=1 \mid x)=b s(\text { tg })+b s(t r)+r r+b s(\text { phum })+b s(\text { wind })+b s(t c c)+w r
$$


with $b s($.$) B-spline [59] with four degrees of freedom, t g$ mean temperature, $t r$ daily temperature range, phum percent humidity, $r r$ precipitation, wind daily wind speed, tcc percent cloud cover, and $w r$ wine region dummy variable. The daily temperature range allowed us to avoid multicollinearity with mean temperature while preserving available information. The model was estimated with the gam and mgcv libraries of the R statistical software.

Finally, we applied the method of "univariate response curves" to the model [60]. Univariate response curves are commonly used to represent the complexity of the relationships between the dependent variable and a single independent variable of a nonlinear multivariate model. They are plotted by calculating the predicted probability of occurrence against the predictor of interest, while keeping all other predictors at their median values. We constructed the response curves using the R software plotmo library [61].

\subsection{Climate Change Simulation}

To simulate the probability of presence of wine tourists, we added 20 and 40 years to the date of shooting of the points of both presence and pseudo-absence; we then performed a geographic overlay operation on the grid corresponding to each simulated future date of shooting of the photo using the I data from the RCP6.0 scenario. Future climate data were input into the GAM model using the predict function of the R library mgcv to calculate the predicted probability values of the presence of wine tourists in the future.

\section{Results}

\subsection{Exploratory Analysis of Model Dataset}

We downloaded data for a total of 34,758 photo points. The wine region with the highest number of photos is La Rioja (8840), followed by Alsace (7020), Chianti (6585), Mosel (6521), and Langhe Monferrato (5792). Figure 2 shows conspicuous seasonal trends in the presence of wine tourists in the five study areas. The tourist season is rather long from May to October with a peak of presence in the summer, more marked for Rioja and less for Chianti and Langhe Monferrato. Winter months have very low presences.

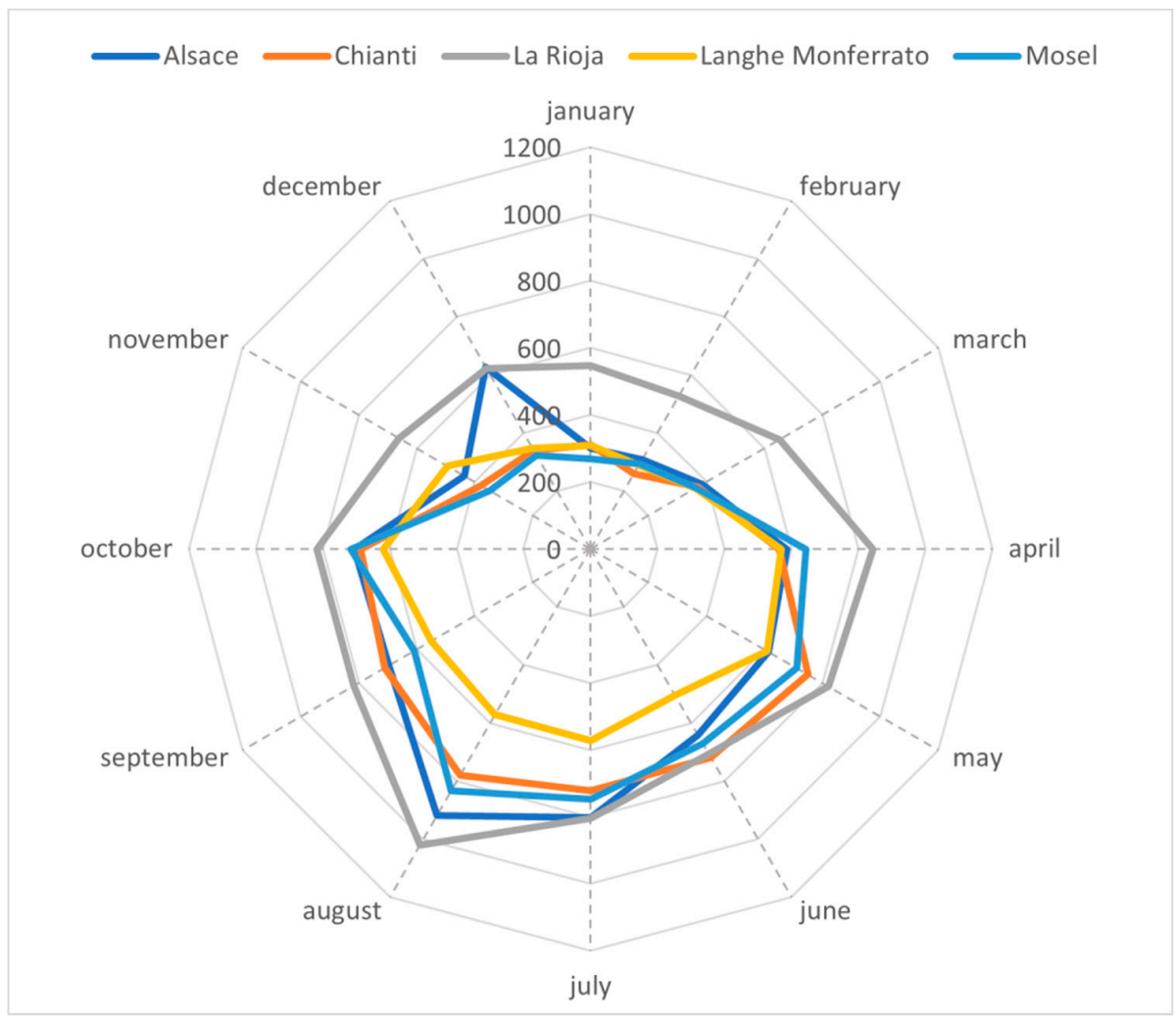

Figure 2. Distribution of Flickr images per month. 
We analyze the current climate and climate change in the five wine regions under study. Figure 3 shows the density plots of the variables processed with the data downloaded from the Copernicus Climate website. The temperature variables show a marked increase, with higher median values of about $12{ }^{\circ} \mathrm{C}$ for the mean temperature, and $10^{\circ} \mathrm{C}$ for the minimum and maximum temperatures. Precipitation tends to increase, especially on rare events, but most frequently there are days with little or no precipitation. The average daily wind speed tends not to change appreciably in the three periods considered. Finally, percent humidity and cloud cover have multimodal distributions: the former tends to have higher values while the latter increases on days with clear skies.
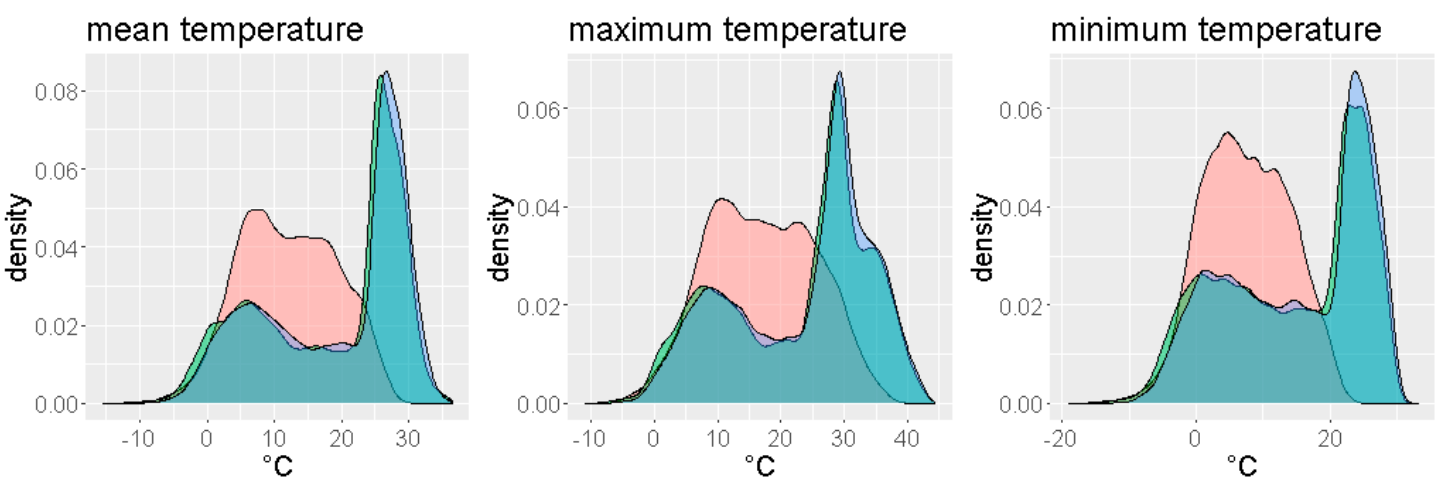

precipitation
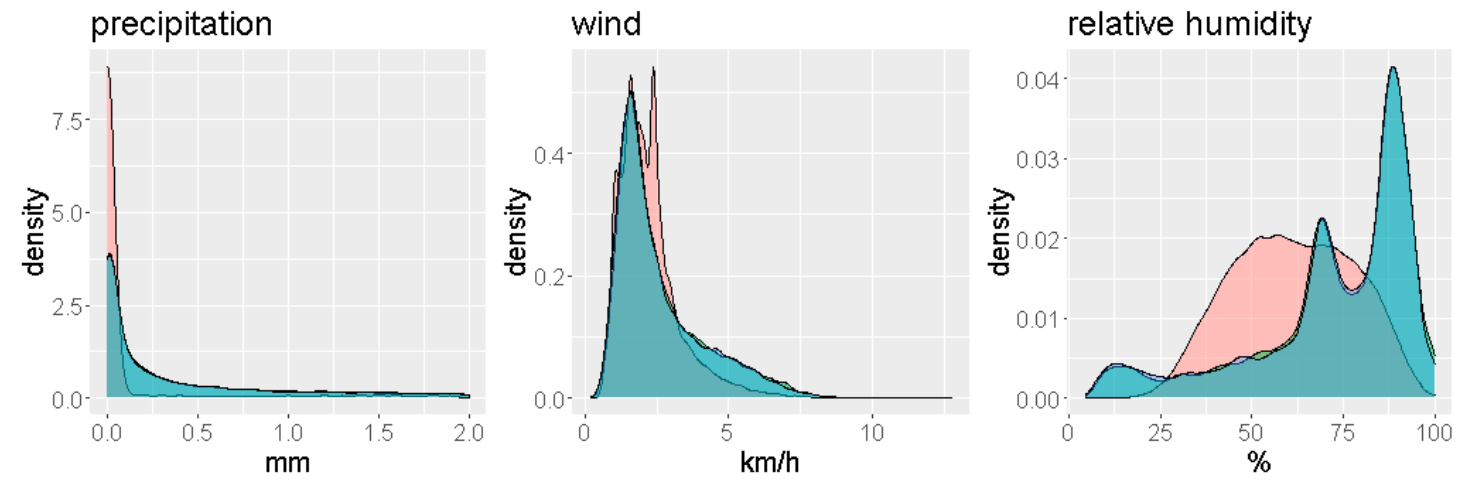

total cloud cover

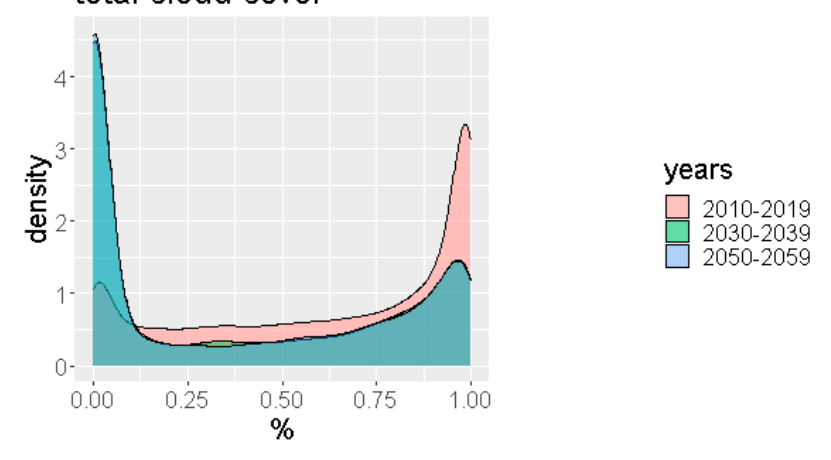

Figure 3. Density plots of climate variables.

\subsection{The GAM Model}

The GAM model is suitable for estimating the response relationship between the probability of presence of a wine tourist and the climatic variables. Analysis of the Variance Inflation Factor (VIF, Table 1) shows that there is no multicollinearity among the independent variables, since all VIFs are less than 10 [62]. Table 2 shows the coefficients, standard errors, and significance of the GAM model parameters. All coefficients are significant with a $p$-value $<0.1$ and most with $p$-value $<0.001$. Finally, the AUC of 0.78 shows that the model is an accurate classifier (Figure 4). 
Table 1. Variance inflation factor (VIF).

\begin{tabular}{cc}
\hline Variable & VIF \\
\hline Percent humidity & 2.75 \\
Mean temperature & 1.81 \\
Precipitation & 1.19 \\
Wind speed & 1.09 \\
Cloud cover & 1.86 \\
\hline
\end{tabular}

Table 2. Estimated results from generalized additive model. Significance codes: ${ }^{* * *} p$-value $<0.001$ ** $p$-value $<0.01,{ }^{*} p$-value $<0.05, p$-value $<0.1$.

\begin{tabular}{cccccc}
\hline Parametric Coefficients: & Estimate & Std. Error & $z$ value & $\operatorname{Pr}(>|z|)$ & \\
\hline (Intercept) & -3.28047 & 0.14455 & -22.695 & $<2 \times 10^{-16}$ & $* * *$ \\
Chianti Classico & -0.51845 & 0.02898 & -17.889 & $<2 \times 10^{-16}$ & $* * *$ \\
Langhe Monferrato & -0.19927 & 0.02874 & -6.932 & $4.14 \times 10^{-12}$ & $* * *$ \\
La Rioja & -0.5612 & 0.02724 & -20.603 & $<2 \times 10^{-16}$ & $* * *$ \\
Mosel & -0.36304 & 0.02967 & -12.238 & $<2 \times 10^{-16}$ & $* * *$ \\
Percent humidity node 1 & 0.42655 & 0.07646 & 5.579 & $2.43 \times 10^{-8}$ & $* * *$ \\
Percent humidity node 2 & 0.19327 & 0.07085 & 2.728 & 0.006376 & $* *$ \\
Percent humidity node 3 & -0.18205 & 0.09029 & -2.016 & 0.043773 & $*$ \\
Mean temperature node 1 & 0.77641 & 0.09469 & 8.199 & $2.42 \times 10^{-16}$ & $* * *$ \\
Mean temperature node 2 & 1.77848 & 0.0859 & 20.704 & $<2 \times 10^{-16}$ & $* * *$ \\
Mean temperature node 3 & 2.05635 & 0.10606 & 19.389 & $<2 \times 10^{-16}$ & $* * *$ \\
Precipitation & -0.2646 & 0.15648 & -1.691 & 0.090853 & \\
Wind speed node 1 & 1.87338 & 0.11682 & 16.037 & $<2 \times 10^{-16}$ & $* * *$ \\
Wind speed node 2 & 2.21186 & 0.08645 & 25.584 & $<2 \times 10^{-16}$ & $* * *$ \\
Wind speed node 3 & 3.58592 & 0.13765 & 26.051 & $<2 \times 10^{-16}$ & $* * *$ \\
Wind speed node 4 & 0.61104 & 0.27339 & 2.235 & 0.025413 & $*$ \\
Cloud cover node 1 & -0.07541 & 0.03527 & -2.138 & 0.032503 & $*$ \\
Cloud cover node 2 & -0.11123 & 0.03207 & -3.468 & 0.000523 & $* * *$ \\
Cloud cover node 3 & -0.42266 & 0.03421 & -12.355 & $<2 \times 10^{-16}$ & $* * *$ \\
Temperature range node 1 & 0.26303 & 0.06526 & 4.031 & $5.56 \times 10^{-5}$ & $* * *$ \\
Temperature range node 2 & 0.18322 & 0.05775 & 3.173 & 0.001511 & $* *$ \\
Temperature range node 3 & -0.37023 & 0.08861 & -4.178 & $2.94 \times 10^{-5}$ & $* * *$ \\
\hline
\end{tabular}

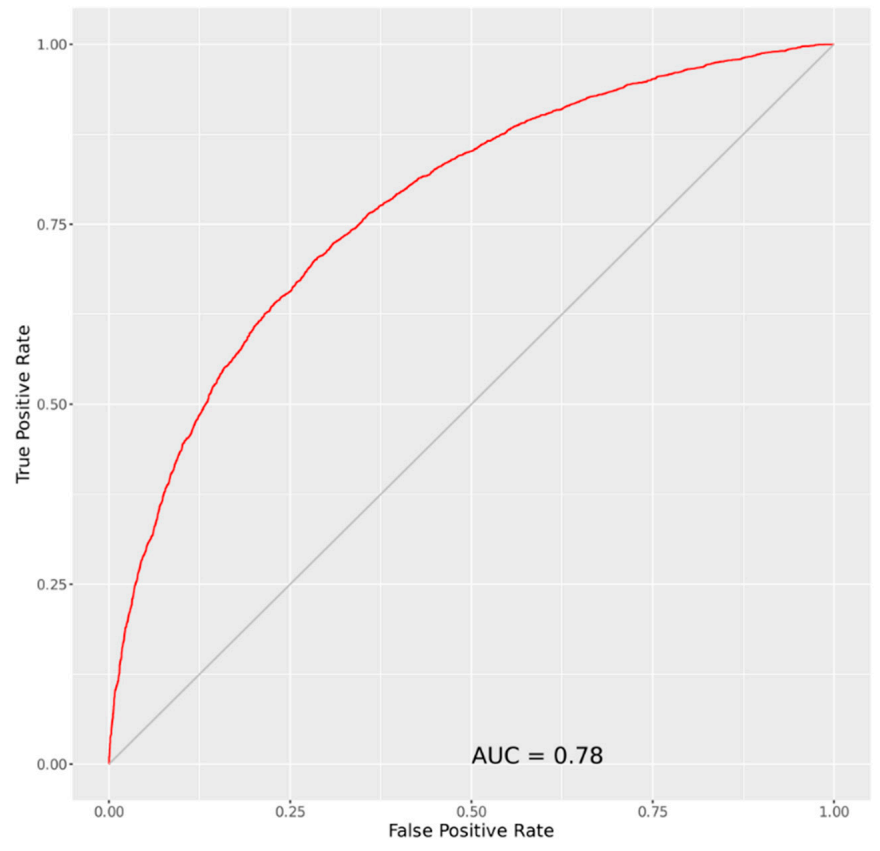

Figure 4. The ROC curve. 
Figure 5 shows the univariate response curves of the model variables. Examining the range of variation of the ordinate axis, we notice that the variables determining the greater variation in the probability of the presence of a tourist are the daily temperature (range of variation from 0.3 to almost 0.7 ) and the average wind speed (from 0.25 to 0.72 ). With regard to the trend of the curves, we can determine that the climatic comfort of tourists in wine regions is the following: percentage humidity of $55 \%$; average daily temperature between I 17 and I $30^{\circ} \mathrm{C}$; absence of precipitation; wind speed from about 2 to $6 \mathrm{~m} / \mathrm{s}$; and clear sky.

1 phum

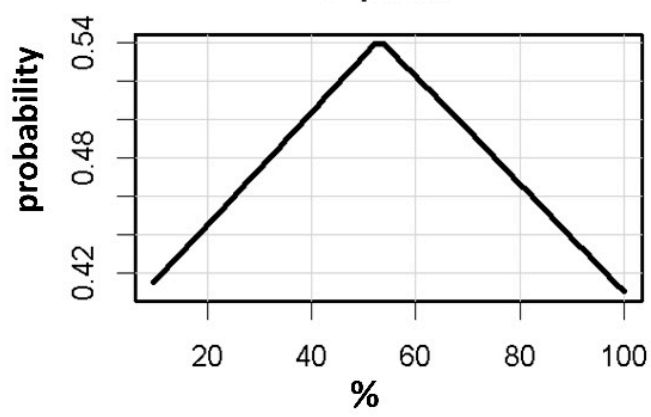

$3 \mathrm{rr}$

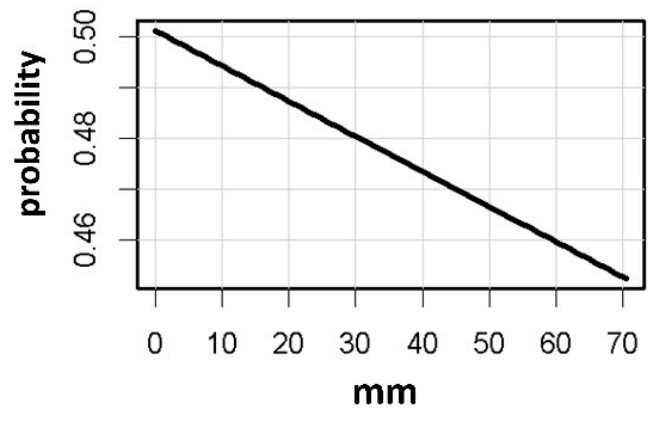

5 tcc

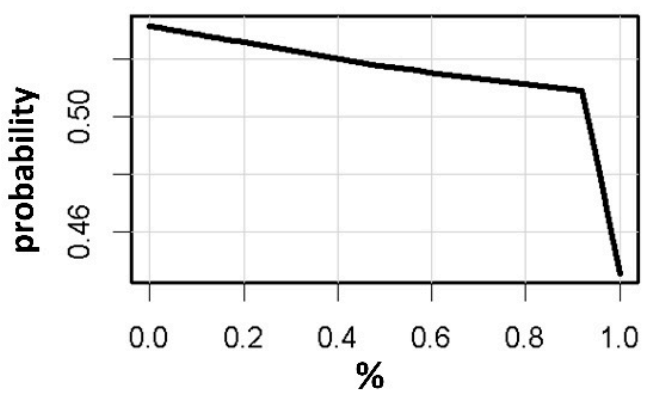

$2 \operatorname{tg}$

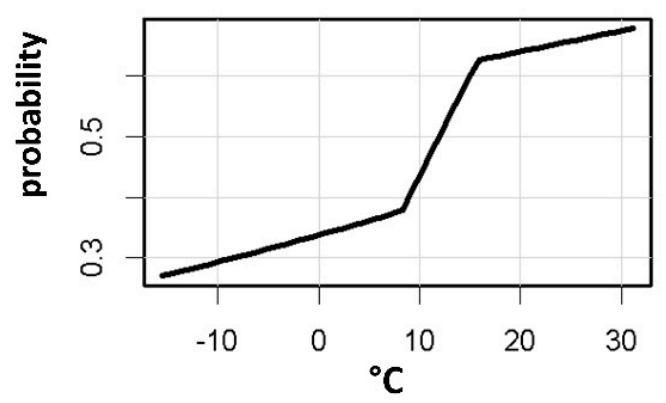

4 wind

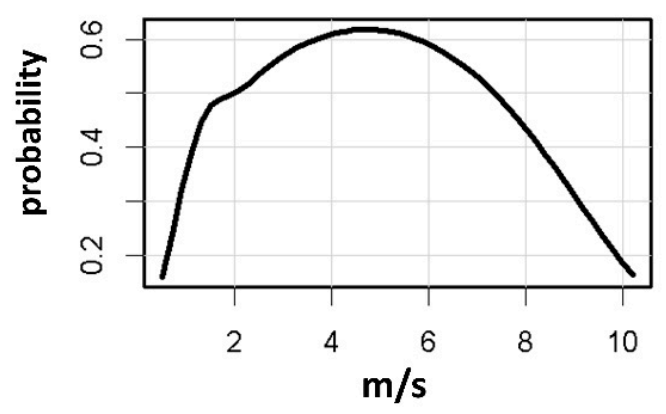

$6 \mathrm{rg}$

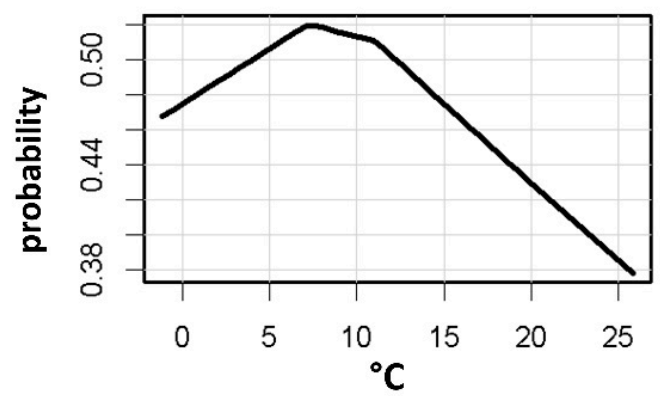

Figure 5. Results from generalized additive model. phum is the percent humidity, $\mathrm{tg}$ is the mean temperature, $\mathrm{rr}$ are precipitations, wind is the wind speed, tcc is the cloud cover, and rg is the temperature range.

\subsection{Future Climate Scenarios}

We performed the simulation of tourist presence in the 5 wine regions using Copernicus Climate model data for the 2030-2039 and 2050-2059 decades (Figure 6). The boxplots of the frequency distributions show that the probability of a tourist presence in the set of all 5 regions increases by applying the data from the future climate scenarios to the GAM model. In fact, the mean probability increases from the current 0.58 to about 0.68 in the future with very similar values in both decades. The probability frequency distribution narrows in the future: the 1 st and 3rd quartiles are, respectively 0.43 and 0.68 in the past 
decade and about 0.63 and 0.74 in the two future decades, again with similar values for the latter ones. The difference between the mean probabilities is significant at $p<0.001$.

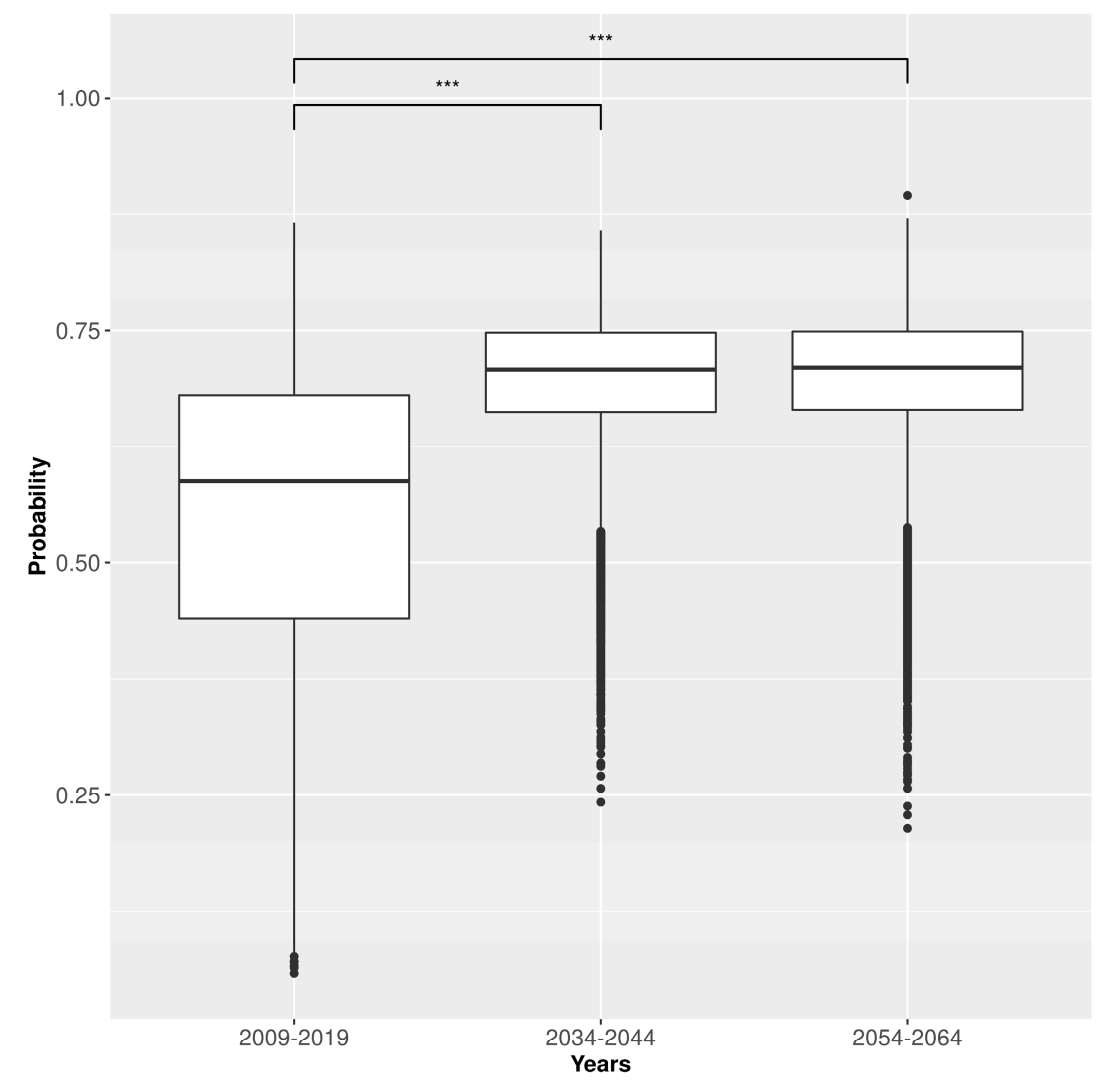

Figure 6. Boxplot showing the probability of current or future visits of a wine tourist. ${ }^{* *}$ difference in mean value with $p<0.001$.

Analyzing the data for the five regions separately (Figure 7), it is possible to highlight differences. The region with the greatest increase in the probability of a tourist's presence is La Rioja, with the mean ranging from 0.55 for the past decade to 0.73 for future decades, with 1st and 3rd quartiles ranging from 0.42 and 0.64 in the past to 0.70 and 0.78 in the future. In contrast, the wine region with the smallest increase is Langhe Monferrato: the average probability increases only from 0.60 to 0.67 , while the quartiles change from 0.42 and 0.72 to 0.62 and 0.71 , respectively. However, the differences between the averages are always highly significant in all the wine regions examined.

Figure 8 shows the monthly median values of the probability of having tourist visits in the five wine regions. Under current climatic conditions, all regions show a marked "summer peak" in the months of June, July and August for Alsace and Mosel and in the months of June to September for the other regions.

In all five regions, the climatic change is projected to increase the period of ideal climatic conditions for the presence of tourists. For Alsace, Langhe Monferrato, and Mosel the summer peak is replaced by a spring peak and the months with the highest probability of tourist presence will be March, April, and May. In La Rioja we can observe a complete deseasonalization of tourism, with an average probability always higher than 0.7. The Chianti Classico wine region is the only one that keeps the summer peak, with an increase in probability of about $100 \%$ in winter months and $15 \%$ in summer months. 


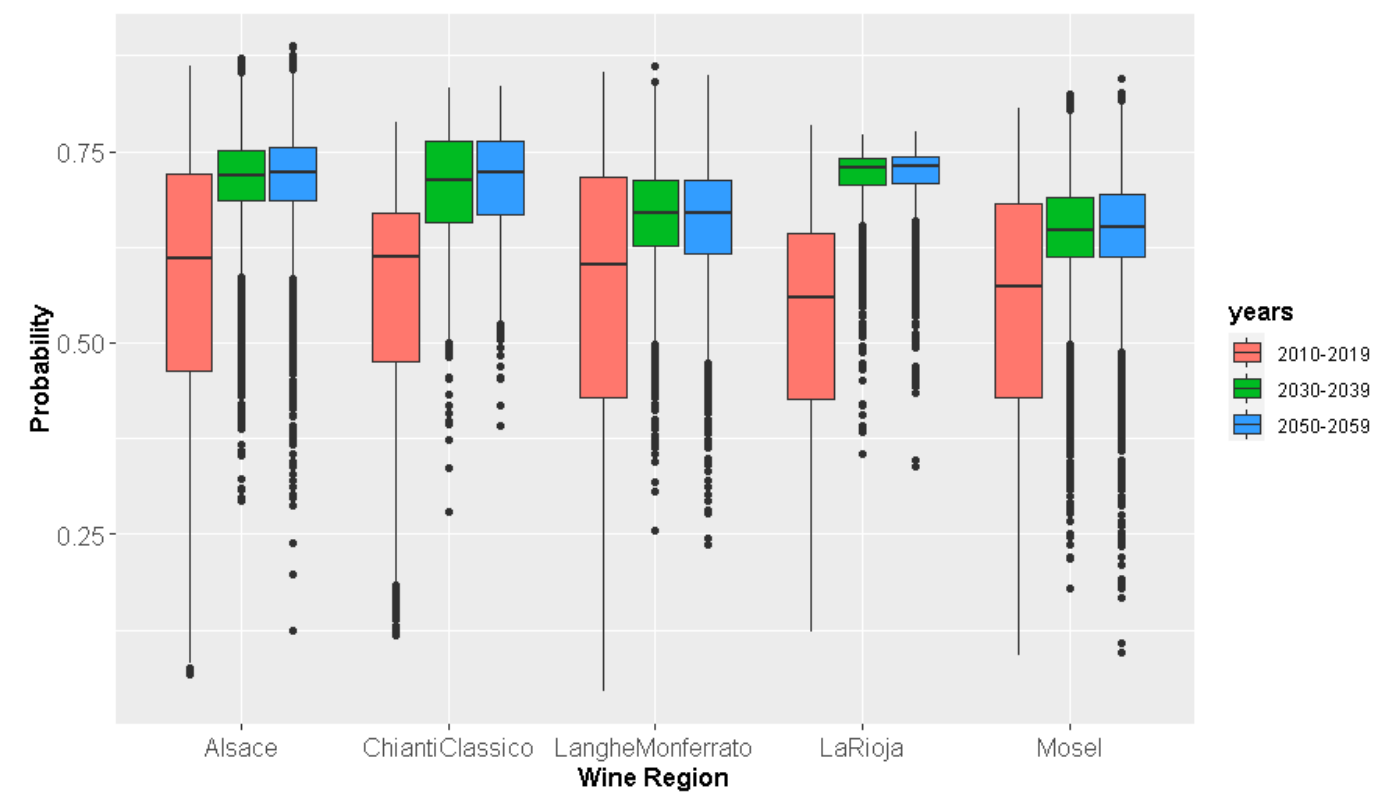

Figure 7. Boxplot per wine region showing the probability of current or future visits of a wine tourist.
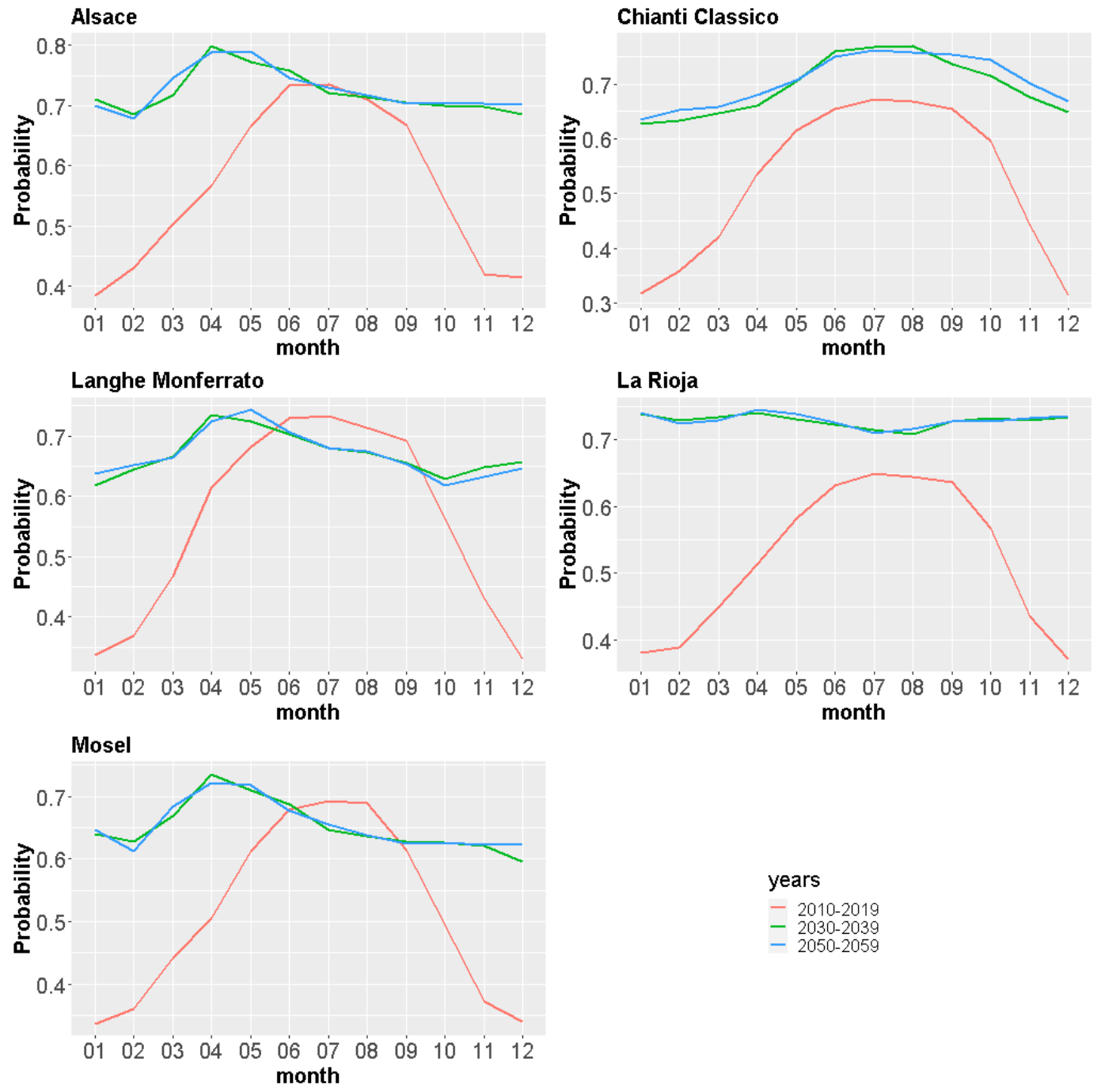

years

- 2010-2019

- $2030-2039$

Figure 8. Seasonality in current and future visits of the wine tourists. 


\section{Discussion}

\subsection{Have the Research Objectives Been Achieved?}

The approach we proposed combines spatiotemporal data from the social platform Flickr with climate data gridded through a non-linear GAM model to predict the presence of tourists. To verify if the obtained results are plausible (RQ1), we compared them with those available in the literature. In particular, we compared the response curves of the GAM model with the parameters used to design one of the most recent index of climate well-being identified for the tourism sector: the Holiday Climate Index (the urban [53] and beach [28] versions).

Regarding temperature, the response curve has the range of maximum contribution to the probability between 16 and $30{ }^{\circ} \mathrm{C}$. In comparison, HCI:urban identifies $20-26{ }^{\circ} \mathrm{C}$ as the optimal range and defines unacceptable temperatures lower than $15^{\circ} \mathrm{C}$ or higher than $31^{\circ} \mathrm{C}$; HCI:beach in Europe has $27-32^{\circ} \mathrm{C}$ for the optimal range and 22 and $37^{\circ} \mathrm{C}$ as unacceptable limits. For precipitation, the response curve decreases from $0 \mathrm{~mm}$, according to HCI:urban and HCI:beach, which set 0 as the ideal value. The percentage of cloud cover causes a sharp decrease in the probability of the response curve for values greater than $90 \%$, while HCI:urban and HCI:beach set this limit at $75 \%$. Finally, with regard to the wind speed, the response curve has a peak in the range of $3-6 \mathrm{~m} / \mathrm{s}$ at $10 \mathrm{~m}$ height; the equivalent speed for HCI:urban and HCI:brach is $0.3-3 \mathrm{~m} / \mathrm{s}$.

In general terms, our research has empirically demonstrated that tourists visiting wine regions accept broader climatic thresholds than those used to construct the $\mathrm{HCI}$ for temperature $\left(20-26{ }^{\circ} \mathrm{C}\right.$ for $\mathrm{HCI}$ versus $16-30{ }^{\circ} \mathrm{C}$ for GAM), global cloud cover $(75 \%$ versus $90 \%$, respectively), and wind $(0.3-3 \mathrm{~m} / \mathrm{s}$ versus $3-6 \mathrm{~m} / \mathrm{s})$. This can be explained by the fact that the visit takes place partly outdoors, with vineyard sightseeing, and partly indoors, with winery visits and wine tasting.

Overall, the results of this study have important implications for the response of tourism demand to climate change in European wine regions (RQ2). Climate change appears to potentially favor tourism in grape growing climates by deseasonalizing flows and shifting frequency peak to the spring period. This result is broadly in line with what has been found by applying future climate data to HCI:urban [63] and from studies using revealed and observed preference methods [53,64]. The main problem that causes the effects of seasonality is the underutilization of wine tourism infrastructure (tasting rooms, wine routes, etc.) in the low season and the almost total occupation of them in the high season. The deseasonalization of wine tourist flows can help diversify offerings by revitalizing the hinterland, as well as promote job creation and rural development, as stated by several authors [65]. However, wineries have to organize themselves in order to take advantage of the changing seasons in the presence of tourists. The organization of the visit at the cellar door must change in winter seasons due to the shorter hours of light, compared to spring and summer. It will also be necessary to use innovative information technologies [66] to explain the typical seasonal phases of wine production (grape harvesting and wine making).

\subsection{Limitation of Study and Topics for Further Research}

The research has some limitations that will need to be addressed in future studies. First, it only partially addresses RQ2, as we demonstrated a potential increase in the probable presence of tourists due to climate change, but not an actual shift in flows from competing destinations. Further studies are needed to apply the methodology proposed to beach, urban, and nature-based tourism to compare the impact of climate change and predict destination shifts.

Our work only considers the direct impact of climate change on tourist comfort, but does not consider the indirect impacts on the core resources of wine tourism: wine quality and vineyard landscape. Both issues have already been investigated by previous research $[67,68]$. A limitation of our niche model is that it is based only on meteorological 
variables and thus does not consider climate and landscape changes simultaneously. This might also be an interesting topic for the future development of this approach.

Other limitations concern the use of Flickr spatiotemporal data as a proxy for tourist presence in wine regions. The use of these data can lead to distortions due to the fact that sometimes there may be ideal weather conditions in the territory to take a good picture even in the presence of climatic discomfort for the tourist. We believe that this condition is quite rare as previous studies [69] have shown that sharing an image on Web 2.0 involves two aspects: the quality of the photo and the memory of the emotional state of well-being on the day the photo was taken. Nevertheless, specific verifications will be needed. The use of Flickr data can also lead to underestimation as not all users include wine tourism related words in the title or tags, and this can lead to a loss of data. To solve this limitation, we plan to implement an artificial intelligence based on deep learning procedures to be able to classify the tourist activities shown in the photograph.

\section{Conclusions}

The study proposes a new methodology that combines daily gridded climate data with large spatiotemporal data from the photo-sharing platform Flickr to build tourism-specific climate comfort models. We implemented the model using data from five European wine regions and employed it to investigate the potential impact on tourism flows due to climate change. The results show an increase in the probability of presence and a greater seasonal adjustment of tourism in all study areas and an anticipation of peak presence from summer to spring in three out of five regions. We believe that these results can be useful to public and private stakeholders to adapt the offer of wine tourism services to the changes in demand and to direct the organization of events such as festivals and thematic tours.

Our research is the first to apply human niche models by correlating Flickr platform data with current and future climate variables. This methodology has the advantage that it can be applied globally with very low cost and to many human outdoor recreational activities.

The main limitation of the work is that the results of the model show that with climate change there will be an increase in the probability of tourism in the five wine regions. The actual possible increase in tourist presence depends on the impacts of climate change on tourist destinations competing with wine tourism. Therefore, further research aimed at developing simultaneous equation models is needed to study the actual change in tourism flows. However, we believe that this work is the starting point for a new line of research that will apply the proposed methodology to different tourism activities to evaluate impacts and destination shifts due to climate change.

Author Contributions: The following statements should be used Conceptualization, V.A.S., E.B. and I.B.; methodology, I.B.; software, I.C.; validation, I.B. and E.B.; writing, I.B. and V.A.S. All authors have read and agreed to the published version of the manuscript.

Funding: This research was funded by the University of Florence, grant "UNICESV".

Data Availability Statement: The data presented in this study are openly available in the European Union's Copernicus Climate Change Service project (https:/ / cds.climate.copernicus.eu/ (accessed on 1 July 2021)) and in Flickr image hosting (www.flickr.com (accessed on 1 July 2021)).

Conflicts of Interest: The authors declare no conflict of interest.

\section{References}

1. Hall, C.M.; Longo, A.M.; Mitchell, R.; Johnson, G. Wine tourism in New Zealand. In Wine Tourism around the World; Routledge: London, UK, 2009; pp. 150-174.

2. Winkler, K.J; Nicholas, K.A. More than wine: Cultural ecosystem services in vineyard landscapes in England and California. Ecol. Econ. 2016, 124, 86-98. [CrossRef]

3. Sottini, V.A.; Barbierato, E.; Bernetti, I.; Capecchi, I.; Fabbrizzi, S.; Menghini, S. Winescape perception and big data analysis: An assessment through social media photographs in the Chianti Classico region. Wine Econ. Policy 2019, 8, 127-140. [CrossRef]

4. Getz, D.; Brown, G. Critical success factors for wine tourism regions: A demand analysis. Tour. Manag. 2006, 27, 146-158. [CrossRef] 
5. Galloway, G.; Mitchell, R.; Getz, D.; Crouch, G.; Ong, B. Sensation seeking and the prediction of attitudes and be-haviours of wine tourists. Tour. Manag. 2008, 29, 950-966. [CrossRef]

6. Marzo-Navarro, M.; Pedraja-Iglesias, M. Wine tourism development from the perspective of the potential tourist in Spain. Int. J. Contemp. Hosp. Manag. 2009, 21, 816-835. [CrossRef]

7. Gössling, S.; Scott, D.; Hall, C.M.; Ceron, J.-P.; Dubois, G. Consumer behaviour and demand response of tourists to climate change. Ann. Tour. Res. 2012, 39, 36-58. [CrossRef]

8. Njoroge, J.M. Climate change and tourism adaptation: Literature review. Tour. Hosp. Manag. 2015, 21, 95-108. [CrossRef]

9. Wilson, R. The Impacts of Climate Change on Australian Tourism Destinations Developing Adaptation and Response Strategies-A Scoping Study; CRC for Sustainable Tourism Pty Ltd.: Gold Coast, Australia, 2009.

10. Turton, S.; Dickson, T.; Hadwen, W.; Jorgensen, B.S.; Pham, T.; Simmons, D.; Tremblay, P.; Wilson, R. Developing an approach for tourism climate change assessment: Evidence from four contrasting Australian case studies. J. Sustain. Tour. 2010, 18, 429-447. [CrossRef]

11. Gómez-Martín, M.B.; Armesto-López, X.A.; Cors-Iglesias, M.; Muñoz-Negrete, J. Adaptation strategies to climate change in the tourist sector: The case of coastal tourism in Spain. Tour. Int. Interdiscip. J. 2014, 62, 293-308.

12. Zsarnoczky, M. The future of sustainable rural tourism development-The impacts of climate change. Ann. Pol. Assoc. Agric. Agribus. Econ. 2017, XIX, 337-344. [CrossRef]

13. Kubokawa, H.; Inoue, T.; Satoh, M. Evaluation of the Tourism Climate Index over Japan in a Future Climate Using a Statistical Downscaling Method. J. Meteorol. Soc. Jpn. 2014, 92, 37-54. [CrossRef]

14. Ghanbari, S.; Karimi, J. The Review of Changes in Tourism Climate Index (TCI) Isfahan (2005-1976). J. Reg. Plan. 2014, 3, 71-82.

15. Pröbstl-Haider, U.; Haider, W.; Wirth, V.; Beardmore, B. Will climate change increase the attractiveness of summer destinations in the European Alps? A survey of German tourists. J. Outdoor Recreat. Tour. 2015, 11, 44-57. [CrossRef]

16. Atzori, R.; Fyall, A.; Miller, G. Tourist responses to climate change: Potential impacts and adaptation in Florida's coastal destinations. Tour. Manag. 2018, 69, 12-22. [CrossRef]

17. Craig, C.A. The Weather-Proximity-Cognition (WPC) framework: A camping, weather, and climate change case. Tour. Manag. 2019, 75, 340-352. [CrossRef]

18. Li, J.; Xu, L.; Tang, L.; Wang, S.; Li, L. Big data in tourism research: A literature review. Tour. Manag. 2018, 68, 301-323. [CrossRef]

19. Gao, H.J.; Li, J.Y. The correlation between tourists' emotion and climate comfort index based on the micro-blog big data: A case study of domestic tourists in Xi'an city. J. Shaanxi Norm. Univ. (Nat. Sci. Ed.) 2017, 45, 110-117.

20. Ren, Y.; Liu, C.; Tang, X. A Correlation Analysis of Nanjing Climate Comfort Degree for Tourism \& Travel Heat Index Changes of the Year based on the Big Data of Multiple Internet. J. Hebei Tour. Vocat. Coll. 2017, 4, 5-10.

21. Grasso, V.; Crisci, A.; Morabito, M.; Nesi, P.; Pantaleo, G. Public crowdsensing of heat waves by social media data. Adv. Sci. Res. 2017, 14, 217-226. [CrossRef]

22. Liu, J.; Yang, L.; Zhou, H.; Wang, S. Impact of climate change on hiking: Quantitative evidence through big data mining. Curr. Issues Tour. 2020, 1-17. [CrossRef]

23. Matzarakis, A. Assessment method for climate and tourism based on daily data. Dev. Tour. Climatol. 2007, 1, 1-7.

24. Scott, D.; McBoyle, G. Using a 'tourism climate index'to examine the implications of climate change for climate as a tourism resource. In Proceedings of the First International Workshop on Climate, Tourism and Recreation, Halkidiki, Greece, 5-10 October 2001; Porto Carras, International Society of Biometeorology: Sithonia, Greece, 2001; pp. 69-88.

25. Fisichelli, N.A.; Schuurman, G.W.; Monahan, W.B.; Ziesler, P.S. Protected Area Tourism in a Changing Climate: Will Visitation at US National Parks Warm Up or Overheat? PLoS ONE 2015, 10, e0128226. [CrossRef] [PubMed]

26. Coldrey, K.M.; Turpie, J.K. Potential impacts of changing climate on nature-based tourism: A case study of South Africa's national parks. Koedoe 2020, 62, 12. [CrossRef]

27. Scott, D.; Rutty, M.; Amelung, B.; Tang, M. An inter-comparison of the holiday climate index (HCI) and the tour-ism climate index (TCI) in Europe. Atmosphere 2016, 7, 80. [CrossRef]

28. Droulia, F.; Charalampopoulos, I. Future Climate Change Impacts on European Viticulture: A Review on Recent Scientific Advances. Atmosphere 2021, 12, 495. [CrossRef]

29. Köberl, J.; Prettenthaler, F.; Bird, D.N. Modelling climate change impacts on tourism demand: A comparative study from Sardinia (Italy) and Cap Bon (Tunisia). Sci. Total Environ. 2016, 543, 1039-1053. [CrossRef] [PubMed]

30. Perch-Nielsen, S.L.; Amelung, B.; Knutti, R. Future climate resources for tourism in Europe based on the daily Tourism Climatic Index. Clim. Chang. 2010, 103, 363-381. [CrossRef]

31. Elith, J.; Leathwick, J.R. Species Distribution Models: Ecological Explanation and Prediction across Space and Time. Annu. Rev. Ecol. Evol. Syst. 2009, 40, 677-697. [CrossRef]

32. Bateman, B.L.; Vanderwal, J.; Johnson, C.N. Nice weather for bettongs: Using weather events, not climate means, in species distribution models. Ecography 2012, 35, 306-314. [CrossRef]

33. Levin, N.; Lechner, A.; Brown, G. An evaluation of crowdsourced information for assessing the visitation and perceived importance of protected areas. Appl. Geogr. 2017, 79, 115-126. [CrossRef]

34. Yoshimura, N.; Hiura, T. Demand and supply of cultural ecosystem services: Use of geotagged photos to map the aesthetic value of landscapes in Hokkaido. Ecosyst. Serv. 2017, 24, 68-78. [CrossRef] 
35. Walden-Schreiner, C.; Leung, Y.F.; Tateosian, L. Digital footprints: Incorporating crowdsourced geographic infor-mation for protected area management. Appl. Geogr. 2018, 90, 44-54. [CrossRef]

36. Bernetti, I.; Alampi Sottini, V.; Bambi, L.; Barbierato, E.; Borghini, T.; Capecchi, I.; Saragosa, C. Urban Niche Assessment: An Approach Integrating Social Media Analysis, Spatial Urban Indicators and Geo-Statistical Techniques. Sustainability 2020, $12,3982$. [CrossRef]

37. Sottini, V.A.; Barbierato, E.; Bernetti, I.; Capecchi, I.; Fabbrizzi, S.; Menghini, S. Rural environment and land-scape quality: An evaluation model integrating social media analysis and geostatistics techniques. Aestimum 2019, 43-62. [CrossRef]

38. Sottini, V.A.; Barbierato, E.; Bernetti, I.; Capecchi, I.; Fabbrizzi, S.; Menghini, S. The use of crowdsourced geo-graphic information for spatial evaluation of cultural ecosystem services in the agricultural landscape: The case of Chianti Classico (Italy). New Medit. 2019, 18, 105-118. [CrossRef]

39. Compés Lopez, R.; Szolnoki, G. Culture and Wine Tourism. In Sustainable and Innovative Wine Tourism Success Models from All around the World; Cajamar Caja Rural: Valencia, Spain, 2021.

40. Frochot, I. Wine tourism in France: A paradox? In Wine Tourism around the World; Routledge: London, UK, 2009; pp. 67-80.

41. Brunori, G.; Rossi, A. Differentiating countryside: Social representations and governance patterns in rural areas with high social density: The case of Chianti, Italy. J. Rural. Stud. 2007, 23, 183-205. [CrossRef]

42. Giovanni, P.; Fabio, P.; Maria, B.P.; Alessandro, B. Food and Wine Tourism in the Langa del Barolo: Survey on Restaurant Offer. Micro Macro Mark. 2017, 1, 27-44.

43. Job, H.; Murphy, A. Germany's Mosel Valley: Can tourism help preserve its cultural heritage? Tour. Rev. Int. 2006, 9, 333-347. [CrossRef]

44. Sessions, C.; Wood, S.A.; Rabotyagov, S.; Fisher, D.M. Measuring recreational visitation at U.S. National Parks with crowd-sourced photographs. J. Environ. Manag. 2016, 183, 703-711. [CrossRef]

45. Cox, A.M.; Clough, P.D.; Marlow, J. Flickr: A first look at user behaviour in the context of photography as serious leisure. Inf. Res. 2008, 13, 336. Available online: http:/ /nformationR.net/ir/13-1/paper336.html (accessed on 6 January 2008).

46. Liu, I.; Norman, W.C.; Pennington-Gray, L. A flash of culinary tourism: Understanding the influences of online food photography on people's travel planning process on flickr. Tour. Cult. Commun. 2013, 13, 5-18. [CrossRef]

47. Barros, C.; Moya-Gómez, B.; García-Palomares, J.C. Identifying Temporal Patterns of Visitors to National Parks through Geotagged Photographs. Sustainability 2019, 11, 6983. [CrossRef]

48. Van der Linden, P.; Mitchell, J.E. Ensembles: Climate Change and Its Impacts: Summary of Research and Results from the ENSEMBLES Project; Met Office Hadley Centre: Exeter, UK, 2009; p. 160.

49. Hurrell, J.; Visbeck, M.; Pirani, A. WCRP Coupled Model Intercomparison Project-Phase 5; Special Issue of the CLIVAR Exchanges Newsletter; International CLIVAR Project Office: Bracknell, UK, 2011.

50. Betts, R.A.; Golding, N.; Gonzalez, P.; Gornall, J.; Kahana, R.; Kay, G.; Mitchell, L.; Wiltshire, A. Climate and land use change impacts on global terrestrial ecosystems and river flows in the HadGEM2-ES Earth system model using the repre-sentative concentration pathways. Biogeosciences 2015, 12, 1317-1338. [CrossRef]

51. Scott, D.; Gössling, S.; De Freitas, C. Preferred climates for tourism: Case studies from Canada, New Zealand and Sweden. Clim. Res. 2008, 45, 61-73. [CrossRef]

52. Rutty, M.; Scott, D. Will the Mediterranean become "too hot" for tourism? A reassessment. Tour. Hosp. Plan. Dev. 2010, 7, 267-281. [CrossRef]

53. Rutty, M.; Scott, D. Differential climate preferences of international beach tourists. Clim. Res. 2013, 57, 259-269. [CrossRef]

54. Rutty, M.; Scott, D. Comparison of Climate Preferences for Domestic and International Beach Holidays: A Case Study of Canadian Travelers. Atmosphere 2016, 7, 30. [CrossRef]

55. Charalampopoulos, I. A comparative sensitivity analysis of human thermal comfort indices with generalized additive models. Theor. Appl. Clim. 2019, 137, 1605-1622. [CrossRef]

56. Du, D.; Zhao, X.; Huang, R. The impact of climate change on developed economies. Econ. Lett. 2017, 153, 43-46. [CrossRef]

57. He, P.; Qiu, Y.; Wang, Y.D.; Cobanoglu, C.; Ciftci, O.; Liu, Z. Loss of profit in the hotel industry of the United States due to climate change. Environ. Res. Lett. 2019, 14, 084022. [CrossRef]

58. Swets, J.A. Measuring the accuracy of diagnostic systems. Science 1988, 240, 1285-1293. [CrossRef] [PubMed]

59. Perperoglou, A.; Sauerbrei, W.; Abrahamowicz, M.; Schmid, M. A review of spline function procedures in R. BMC Med. Res. Methodol. 2019, 19, 1-16. [CrossRef] [PubMed]

60. Elith, J.; Ferrier, S.; Huettmann, F.; Leathwick, J. The evaluation strip: A new and robust method for plotting pre-dicted responses from species distribution models. Ecol. Model. 2005, 186, 280-289. [CrossRef]

61. Milborrow, S. Plotmo: Plot a Model's Residuals, Response, and Partial Dependence Plots; R Foundation for Statistical Computing: Vienna, Austria, 2018.

62. Kim, J.H. Multicollinearity and misleading statistical results. Korean J. Anesthesiol. 2019, 72, 558-569. [CrossRef] [PubMed]

63. Rutty, M.; Scott, D.; Matthews, L.; Burrowes, R.; Trotman, A.; Mahon, R.; Charles, A. An inter-comparison of the holiday climate index (HCI: Beach) and the tourism climate index (TCI) to explain Canadian tourism arrivals to the Caribbe-an. Atmosphere 2020, 11, 412. [CrossRef]

64. Moreno, A. Mediterranean Tourism and Climate (Change): A Survey-Based Study. Tour. Hosp. Plan. Dev. 2010, 7, 253-265. [CrossRef] 
65. Armas, R.J.D. Potencialidad e Integración Del ‘Turismo Del Vino' En Un Destino de Sol y Playa: El Caso de Tenerife. PASOS Rev. Tur. Patrim. Cult. 2008, 6, 199-212.

66. Garibaldi, R.; Sfodera, F. Technologies for enhancing wine tourism experience. In The Routledge Handbook of Tourism Experience Management and Marketing; Routledge: London, UK, 2020; Volume 16, pp. 409-417. [CrossRef]

67. Ashenfelter, O.; Storchmann, K. Climate Change and Wine: A Review of the Economic Implications. J. Wine Econ. 2016, 11, 105-138. [CrossRef]

68. Gurbey, A.P. Climate change problems in agricultural landscape areas: Eastern thrace vineyards. J. Environ. Prot. Ecol. 2020, 21, 1090-1097.

69. Nov, O.; Naaman, M.; Ye, C. Analysis of participation in an online photo-sharing community: A multidimensional perspective. J. Am. Soc. Inf. Sci. Technol. 2010, 61, 555-566. [CrossRef] 